\title{
Stand Age, Precipitation, and Temperature Effects on Forage Yield
}

\author{
LARRY M. WHITE
}

\begin{abstract}
The effects of seasonal distribution of precipitation on forage yield are often confounded by stand age. Forage yields of Russian wildrye (Psathyrostachys junceus), green needlegrass (Stipa viridula), crested wheatgrass (Agropyron desertorum), and intermediatepubescent wheatgrass (Agropyron intermedium-trichophorum) were determined from 6 separate studies, each of 6 years duration, from 4 locations in the northern Great Plains. Stepwise multiple regression showed that forage yield of all 4 species was significantly $(P<0.01)$ related with April and May precipitation and stand age. Forage yield of Russian wildrye was sienificantly $(P<0.05)$ related with April mean monthly temperature and degree days (accumulation of daily mean air temperature above a given threshold temperature) accumulated until the end of May or June; however, yields of the other 3 species were not significantly related with April, May, or June mean monthly temperatures nor degree days accumulated until the end of May or June. The highest forage yield per centimeter of precipitation occurred either the second or third year after establishment; then yield decreased asymptotically and by year 5 or 6 was only $75 \%$ of maximum for green needlegrass and $40-50 \%$ for the other grasses. Economic evaluation of seeding forages must include the influence of stand age on forage yield.
\end{abstract}

Methods are needed to determine potential forage yield of seed range grasses without having to test each species for 5 to 10 years at numerous locations. Kilcher and Heinrichs (1974) found that forage production the first year after establishment was 2 to 3 times greater than their 7-year average. Except for Russian wildrye (Psathyrostachys junceus), forage species tested by Currie and Smith (1970) yielded the most forage during the third year after establishment. Russian wildrye required 5 years to reach its highest forage production. Kilcher (1980) suggested that when ranking a species forage production potential, the first harvest year data be ignored and only data for the following 5 consecutive years be used. Six years seems to be an excessively long requirement for evaluation of forage species.

A number of researchers have found forage production was highly correlated with seasonal precipitation. Stitt (1958) noted that forage yield of a number of grass species had higher correlations $(r=0.88)$ with April through May precipitation than with April through June precipitation $(r=0.54)$. Smoliak (1956) found forage yield of native range had higher correlation $(r=0.86)$ with May through June precipitation than with precipitation during any other period over a 20 -year period. However, Thomas and Osenbrug (1959) reported forage yields of a mixture of bromegrasscrested wheatgrass (Bromus inermis-Agropyron desertorum) for 8 years were not significantly $((P>0.05)$ correlated $(r=0.53)$ with April through June precipitation. They found that the range of daily temperature combined with precipitation was needed to significantly $((P<0.05)$ correlate $(r=0.84)$ with forage yields. Lawrence and Heinrichs (1968) found, over a 15-year period, that precipitation received during the previous September $(r=0.55)$

\footnotetext{
Author is a range scientist, USDA-ARS, Southern Plains Range Research Station, 2000-18th St., Wood ward, Okla. 73801.

This article is a contribution of U.S. Department Agriculture, Agricultura Research Service, in cooperation with the Montana Agr. Exp. Sta., Sidney. Journal Series No. J-1443.

Manuscript accepted April 19, 1984.
}

along with precipitation received during $\operatorname{March}(r=0.77)$, April $(r=$ $0.49)$, and May $(r=0.62)$ of the current year were significantly $(P<0.05)$ correlated with forage yields of Russian wildrye. Rogler and Haas (1947) reported soil moisture from the previous fall was significantly $(P<0.05)$ correlated $(r=0.73)$ with forage yields of native range at Mandan, N. Dak.

The objective of this report was to investigate the effects of stand age, amount and seasonal distribution of precipitation, mean monthly temperature, degree days (accumulation of daily mean air temperature above a given threshold temperature), and location effect on forage yield of $\mathbf{4}$ grass species in the Northern Great Plains.

\section{Materials and Methods}

Two different analysis methods (stepwise regression and analysis of variance) were used separately to determine the effects of stand age, amount and seasonal distribution of precipitation on forage yields of Russian wildrye, green needlegrass (Stipa viridula), crested wheatgrass, and intermediate-pubescent wheatgrass (Agropyron intermedium-trichophorum) as reported in 6 separate studies from the Northern Great Plains [Stitt (1958), Clark and Heinrichs (1957), Whitman et al. (1961 and 1962), Dickinson Experimental Station Annual Report (1968), Nyren et al. (1980), and White and Wight (1984)] (Table 1). Only forage yield the second through the sixth years after establishment was used in this analysis. Forage yield the first year after establishment was excluded because they were highly variable due to differences in stand establishment and to simplify the equations for stand age effect. Forage yields were averaged in instances where more than one cultivar of the same species were included in a study. Data for intermediate and pubescent wheatgrass were combined because analysis of the two species at Dickinson from 1953 to 1958 showed no significant differences in forage yield. The forages were generally harvested in early July, except for those in the Sidney study which were harvested as each species reached anthesis (early to late June depending upon species and year). Daily air temperatures from February through June and monthly precipitation from the previous July through June of the current year were obtained from each location.

\section{Stepwise Regression}

Stepwise (addition and deletion) multiple regression was then employed across the second through sixth years after each species was established to determine the months during which precipitation was most highly correlated with forage yield of each species. Mean monthly temperatures for April, May, and June along with degree days (accumulation of daily mean air temperature above a given threshold temperature) base $-7,-5,-3,-1,1,3,5,7$, and $9^{\circ} \mathrm{C}$ accumulated from the first of February until either the last of May or last of June were added as variables to the stepwise multiple regression to determine if they significantly accounted for variation in forage yield. Temperature data, in addition to monthly precipitation, was run in the following sequence: first, monthly precipitation and mean monthly temperatures; second, monthly precipitation and degree days accumulated to the end of May; and third, monthly precipitation and degree days accumulated to the end of June. 


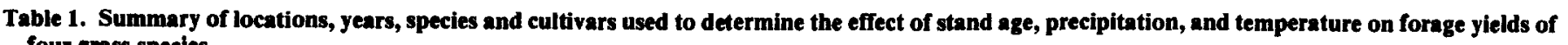
four grass species.

\begin{tabular}{|c|c|c|c|c|c|c|}
\hline \multirow[b]{2}{*}{ Location } & \multirow[b]{2}{*}{ Study years } & \multirow[b]{2}{*}{$\begin{array}{c}\text { Row } \\
\text { Width cm }\end{array}$} & \multicolumn{4}{|c|}{ Cultivars } \\
\hline & & & Russian wildrye & Green needle grass & $\begin{array}{l}\text { Crested } \\
\text { wheatgrass }\end{array}$ & $\begin{array}{l}\text { Intermediate- } \\
\text { Pubescent } \\
\text { wheatgrass }\end{array}$ \\
\hline Moccasin, MT & $1941-46$ & 35 & Common & Green Stipa & $\begin{array}{l}\text { PII9537 } \\
\text { M24-3 } \\
\text { M24-17 }\end{array}$ & \\
\hline Swift Current, Sask. & $1950-54$ & 30 & Common & Green Stipa & Fairway & Ree IW \\
\hline Dickinson, ND & $1953-58$ & 15 & Common & Green Stipa & $\begin{array}{l}\text { Nordan \& } \\
\text { Standard }\end{array}$ & $\begin{array}{l}\text { Common IW } \\
\text { Common PW }\end{array}$ \\
\hline Dickinson, ND & $1959-64$ & 15 & 2355 \& Common & Green Stipa & Summit \& Nordan & Neb. 50 IW \\
\hline Dickinson, ND & $1973-78$ & 15 & Vinall & $\begin{array}{l}\text { Lodorm \& } \\
\text { Green Stipa }\end{array}$ & Nordan & Topar PW \\
\hline Sidney, MT & $1975-80$ & 50 & Mayak & Lodorm & Nordan & Luna PW \\
\hline
\end{tabular}

\section{Analysis of Variance}

Since stepwise multiple regression did not allow for location differences in forage yield, a two-way analysis of variance of forage yield $(\mathrm{kg} / \mathrm{ha}$ ) per centimeter of precipitation was performed to more accurately determine the effects of stand age on forage yield. For a given species, data from the different studies were considered replications; years after establishment were used as treatments. A two-way analysis of variance using only forage yields the second through sixth years from 6 studies at 4 locations was performed. The missing data for green needlegrass the sixth year for the third study at Dickinson were estimated by using a missing-plot technique (Yates 1933).

Forage yields per centimeter of precipitation were calculated first from April through May, then from April through June, March through June, February through June, and so on, up to the maximum period of the previous July through June. April plus May precipitation was used first because the stepwise multiple regression showed that precipitation during this period was significantly correlated ( $r=0.63$ to $0.77, P<0.01$ ) with forage yields. I then determined which period gave the lowest coefficient of variation in yield per centimeter of precipitation over the 5 years and 6 locations for each species. This assumes that precipitation during the period which produces the lowest coefficient of variation in the two-way analysis of variance is the period that best relates precipitation, stand age, and location with forage yield. A similar approach was employed by Arnold (1959) in which the best base temperature in relating degree days with phenology was the one which produced the lowest coefficient of variation.

\section{Results and Discussion}

\section{Stepwise Regression Method}

Stepwise multiple regression of the second through sixth years over all locations for each species showed that precipitation during only April and May was significantly $(P<0.01)$ correlated with forage yields of Russian wildrye (RWR), green needlegrass (GN), crested wheatgrass $(\mathrm{CW})$, and intermediate-pubescent wheatgrass (IPW) with respective correlation coefficients of $0.67,0.77,0.63$, and 0.69. Examination of actual versus estimated forage yields predicted with April plus May precipitation revealed that the regression equations consistently under-estimated yield during the second and third years after establishment and over-estimated them during the fifth and sixth years.

Since it appeared that stand age affected forage yield of the 4 species, this variable was added in the stepwise multiple regression analysis. The following equations describe the relationship of stand age, April and May precipitation (ppt.) to forage yields of 4 species from the second through the sixth years after establishment:

RWR yield $=1120+147$ Apr ppt. +114 May ppt. -242 age, $r=0.76$, Syx $=$ 691

GN yield $=1196+152$ Apr ppt. +82 May ppt. -144 age, $r=0.80$, Syx $=546$ $C W$ yield $=2135+128$ Apr ppt. +115 May ppt. -371 age, $r=0.81$, Syx $=$ 656

IPW yield $=1493+196$ Apr ppt. +145 May ppt. -336 age, $r=0.79$, Syx $=$ 840

where yield $=\mathrm{kg} /$ ha and age $=$ ycars after establishment. Adding stand age decreased the variance of yield $12,5,34$, and $14 \%$ for RWR, GN, CW, and IPW, respectively, over using April and May precipitation only. Each centimeter of April and May precipitation increased forage yield 82 to $196 \mathrm{~kg} /$ ha while stand age decreased forage yield 144 to $371 \mathrm{~kg} /$ ha per each additional year harvested after establishment. Precipitation during August of the previous year significantly decreased forage yield of IPW and RWR by 97 and $99 \mathrm{~kg} / \mathrm{ha}$ per centimeter of precipitation, but had no significant effect on $\mathrm{CW}$ nor $\mathrm{GN}$ yields.

The analysis showed that an increase in April mean monthly temperature by $1^{\circ} \mathrm{C}$ significantly $(P<0.01)$ increased forage yield of RWR by $114 \mathrm{~kg} / \mathrm{ha}$. Degree days base -3 and $-5 \mathrm{C}$ accumulated until the end of May or June, respectively, were significantly correlated with forage yields of RWR and accounted for about $10 \%$ of the yield variation.

RWR yield $=-1275+200$ Apr ppt. +121 May ppt. $+3563(1 /$ age $)-105$ Aug ppt. +114 Apr Temp. C; $r=0.90$, Syx $=471$

RWR yield $=-2659+191$ Apr ppt. +127 May ppt. $+3812(1 /$ age $)-93$ Aug ppt. $+2.19 \mathrm{DD}(-3)$ until May $31 ; \mathrm{r}=0.91$, Syx $=455$

RWR yield $=-2942+174$ Apr ppt. +125 May ppt. $+3737(1 /$ age $)-82$ Aug ppt. + 1.32 DD(-5) until June 30;r $=0.89$, Syx $=496$

where $\mathrm{DD}=$ degree days.

However, forage yields of the other 3 species were not significantly $(P>0.05)$ related with April, May, or June mean monthly temperature nor degree days. The problem in correlating temperature with forage yield is variation among years or locations as to when growth starts and anthesis is reached. Theoretically, if the degree day system accurately accounted for all variations of when anthesis was reached, then the number of degree days to anthesis would be constant among years or locations and would be of no value in correlating it with forage yields. A better method would be to correlate mean daily temperatures between $0-30,30-60$, and 60-90 days before anthesis with forage yields. Anthesis dates were only recorded for the Sidney data and not for data at the other locations. The degree days base $9^{\circ} \mathrm{C}$ which best predicted anthesis at Sidney (White and Wight 1984) could not be used to predict anthesis at Swift Current. Degree days (base $9^{\circ} \mathrm{C}$ based on Sidney 
data predicted anthesis for the $\mathbf{4}$ grasses during July at Swift Current when they were actually in the seed ripe stage.

\section{Analysis of Variance Method}

Stepwise regression did not account for such location differences as soil fertility, stand density, width between rows, and cultivar differences. Thus, forage yield was divided by precipitation received during various periods and a two-way analysis of variance was used to account for location effects. When location effects was accounted for, then precipitation during June, in addition to that received during April and May, greatly reduced the coefficient of variation (Table 2).

Table 2. Coefficient of variation as affected by forage yield per centimeter of precipitation received during various periods during six studies for the second through sixth years after establishment.

\begin{tabular}{lcccc}
\hline \hline Months & $\begin{array}{c}\text { Russian } \\
\text { wildrye }\end{array}$ & $\begin{array}{c}\text { Green } \\
\text { needle- } \\
\text { grass }\end{array}$ & wheatgrass & $\begin{array}{c}\text { Intermediate- } \\
\text { pubescent } \\
\text { wheatgrass }\end{array}$ \\
\hline July'-June & 46.7 & 40.2 & 37.0 & 50.4 \\
August-June & 44.4 & 37.5 & 35.7 & 48.9 \\
September-June & 44.3 & 36.7 & 35.2 & 48.2 \\
October-June & 44.2 & 34.2 & 39.5 & 53.3 \\
November-June & 43.4 & 34.9 & 38.8 & 51.5 \\
December-June & 43.0 & 35.8 & 40.0 & 52.0 \\
January-June & 44.0 & 35.3 & 39.8 & 51.4 \\
February-June & 43.0 & 33.8 & 39.5 & 50.0 \\
March-June & 41.7 & 32.3 & 38.9 & 48.7 \\
April-June & 38.7 & 30.5 & 37.3 & 47.3 \\
April-May & 52.3 & 40.1 & 55.5 & 61.9 \\
\hline
\end{tabular}

$1 \mathrm{July}$ through December are in year before current harvest.

June precipitation was important in relating precipitation with forage yields of all 4 species, on contrast to results of Stitt (1958), and Lawrence and Heinrichs (1968). However, the addition of precipitation during any of the previous months through the pre- vious July increased the coefficient of variation for all grasses except CW. Lawrence and Heinrichs (1968), however, found that inclusion of precipitation during both March and the previous September significantly improved correlation of precipitation with forage yields of RWR. Precipitation from September through June of the current year produced the lowest coefficient of variation for $\mathrm{CW}$ over all locations (Table 2). Forage yield per centimeter of precipitation received from April through June was used to determine the effects of stand age on all species so that the results were comparable.

The average forage yield per centimeter of April through June precipitation reached a maximum in the second or third year after establishment for all species at all locations with only 3 exceptions (Tables 3 through 6). Russian wildrye and IPW at Swift Current and GN during the first study at Dickinson produced low forage yield per centimeter of precipitation the first few years after establishment, probably because of low stand density, then increased over the next few years. Currie and Smith (1970) reported a similar response of RWR.

In general forage yields declined asymptotically, decreasing most rapidly the third and fourth years and started to level off the fifth and sixth years. An equation of $Y=a+(b / x)$, whre $Y=$ forage yield per centimeter of April-June precipitation and $x=$ years after establishment, had the highest correlation of the 7 equations tested in relating stand age effects.

RWR yield $=14.2+(202 /$ age $), r=0.97$

$\mathrm{GN}$ yield $=51.5+(114 / \mathrm{age}), \mathrm{r}=0.95$

$\mathrm{CW}$ yield $=9.32+(301 / \mathrm{age}), \mathrm{r}=0.98$

IPW yield $=8.44+(289 / \mathrm{age}), r=0.99$

where yield $=\mathrm{kg} / \mathrm{ha} / \mathrm{cm}$ April-June precipitation, age $=$ years after establishment. Yields of RWR and wheatgrasses appeared to still be declining the sixth year whereas those of GN appeared to have leveled off (Fig. 1).

Based on these analysis, GN, CW, IPW, and RWR will produce only $75,50,50$, and $40 \%$ as much forage per centimeter of April-June precipitation in the sixth year after establishment as in the

Table 3. Effects of stand age and study location on forage yields of Russian wildrye per centimeter of April-June precipitation received.

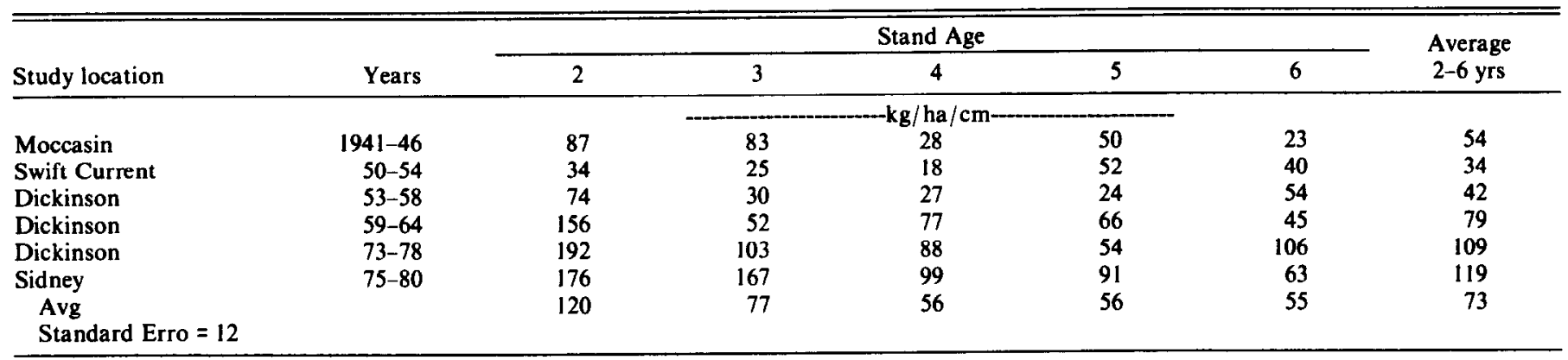

Table 4. Effects of stand age and study location on forage yields of green needlegrass per centimeter of April-June precipitation received.

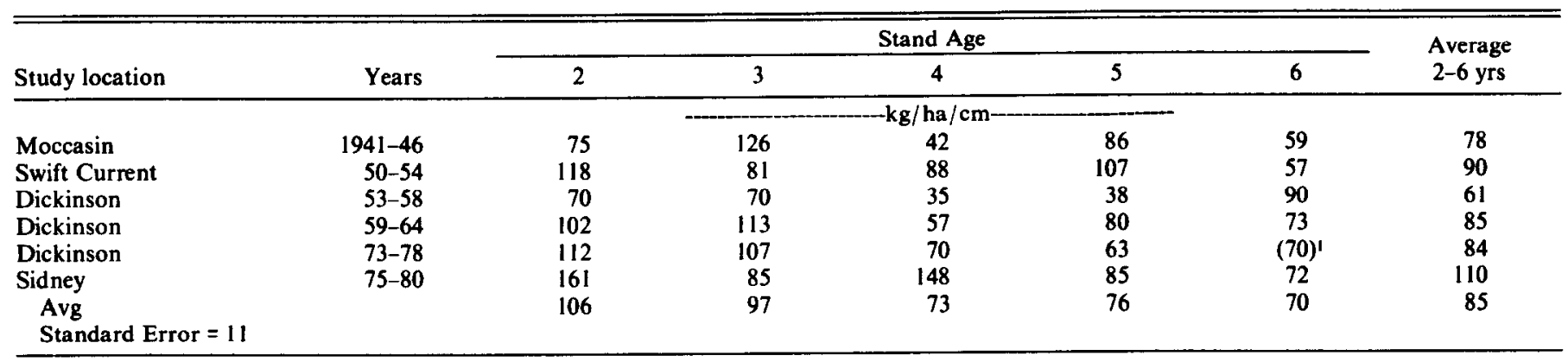

'Missing data, estimated 
Table 5. Erfeets of stand age and study location on forage yields of crested wheatgrass per centimeter of April-June precipitation received.

\begin{tabular}{|c|c|c|c|c|c|c|c|}
\hline \multirow[b]{2}{*}{ Study location } & \multirow[b]{2}{*}{ Years } & \multicolumn{5}{|c|}{ Stand Age } & \multirow{2}{*}{$\begin{array}{l}\text { Average } \\
2-6 \text { yrs }\end{array}$} \\
\hline & & 2 & 3 & 4 & 5 & 6 & \\
\hline $\begin{array}{l}\text { Moccasin } \\
\text { Swift Current } \\
\text { Dickinson } \\
\text { Dickinson } \\
\text { Dickinson } \\
\text { Sidney } \\
\quad \text { Avg } \\
\text { Standard Error }=15\end{array}$ & $\begin{array}{r}1941-46 \\
50-54 \\
53-58 \\
59-64 \\
73-78 \\
75-80\end{array}$ & $\begin{array}{l}153 \\
101 \\
149 \\
255 \\
122 \\
174 \\
159\end{array}$ & $\begin{array}{r}126 \\
62 \\
67 \\
91 \\
143 \\
190 \\
113\end{array}$ & $\begin{array}{l}g / \text { ha } \\
46 \\
40 \\
59 \\
102 \\
110 \\
101 \\
76\end{array}$ & $\begin{array}{r}107 \\
82 \\
52 \\
91 \\
56 \\
102 \\
82\end{array}$ & $\begin{array}{l}31 \\
48 \\
88 \\
53 \\
69 \\
30 \\
53\end{array}$ & $\begin{array}{r}93 \\
66 \\
83 \\
118 \\
100 \\
119 \\
97\end{array}$ \\
\hline
\end{tabular}

Table 6. Effects of stand age and study location on forage yields of intermediate-pubescent wheatgrass per centimeter of April-June precipitation received.

\begin{tabular}{|c|c|c|c|c|c|c|c|}
\hline \multirow[b]{2}{*}{ Study location } & \multirow[b]{2}{*}{ Years } & \multicolumn{5}{|c|}{ Stand Age } & \multirow{2}{*}{$\begin{array}{c}\text { Average } \\
2-6 \text { yrs }\end{array}$} \\
\hline & & 2 & 3 & 4 & 5 & 6 & \\
\hline & \multicolumn{7}{|c|}{$\mathrm{kg} / \mathrm{ha} / \mathrm{cm}$} \\
\hline Swift Current & $1950-54$ & 60 & 47 & 56 & 72 & 64 & 60 \\
\hline Dickinson & $53-58$ & 99 & 63 & 26 & 21 & 25 & 47 \\
\hline Dickinson & $59-64$ & 269 & 53 & 87 & 119 & 68 & 119 \\
\hline Dickinson & $73-78$ & 188 & 157 & 114 & 69 & 82 & 122 \\
\hline Sidney & $75-80$ & 159 & 173 & 121 & 100 & 15 & 114 \\
\hline \multirow{2}{*}{\multicolumn{2}{|c|}{$\begin{array}{l}\text { Avg } \\
\text { Standard Error }=20\end{array}$}} & 155 & 99 & 81 & 76 & 51 & 92 \\
\hline & & & & & & & \\
\hline
\end{tabular}

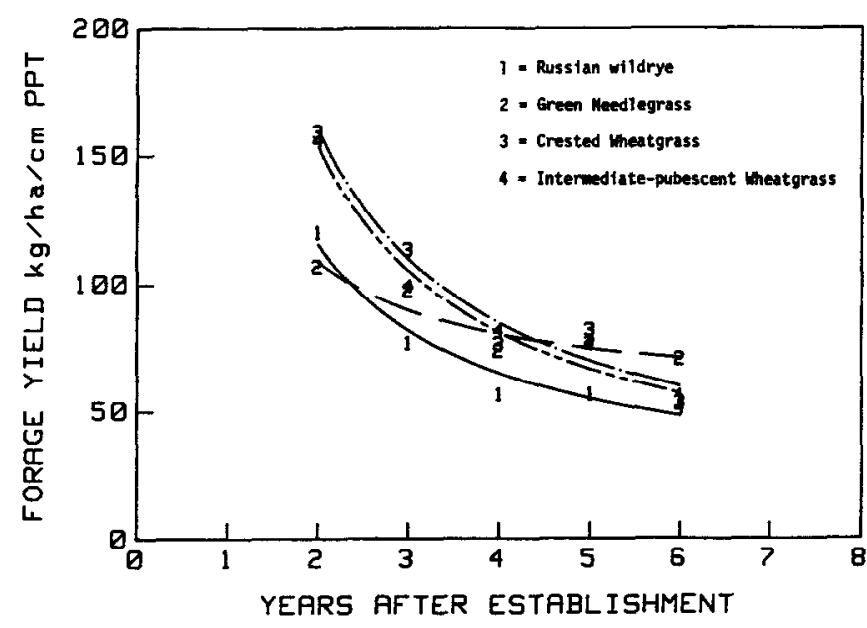

Fig. 1. Average effects of stand age on forage yield per centimeter of April through June precipitation from 6 studies in the Northern Great Plains.

second year. Forage production averaged over all locations the second year after establishment per centimeter of April-June precipitation was 1.7, 1.6, 1.6, and 1.2 times the second through sixth year average for IPW, CW, RWR, and GN, respectively. This is in contrast with 2 to 3 times greater than the 7-year average annual forage yield as reported by Kilcher and Heinrichs (1974) for grassalfalfa (Medicago sativa subsp. varia (Martyn) Arc.) mixtures. However, they did not adjust their figures for difference in precipitation among years.

The F-Test showed that location had no effect $(P>0.05)$ on forage yields per centimeter of precipitation for either $\mathrm{GN}$ or $\mathrm{CW}$ (Tables 4 and 5). Russian wildrye produced more $(P<0.01)$ forage at Sidney and Dickinson $(1959-64,1973-78)$ than at the other study locations (Table 3 ). Russian wildrye probably produced more forage at Sidney because it was seeded in 50-cm rows compared to 15- to 35-cm rows in other studies. Leyshon et al. (1981) showed that increased distance between rows increased forage production of RWR more than that of CW. The improved RWR cultivars, 'Mayak' and 'Vinall', used at Sidney and during the last study at Dickinson may have been higher forage producers than the common RWR used at Moccasin, Swift Current, and first study at Dickinson.

Intermediate-pubescent wheatgrass produced less $(P<0.05)$ forage per centimeter of precipitation at Swift Current and first Dickinson study than at the other 3 locations (Table 6). 'Ree' intermediate wheatgrass was used in the Swift Current study while common intermediate and pubescent wheatgrasses were used in the first study at Dickinson. 'Nebraska 50' intermediate wheatgrass was used in the second study at Dickinson, while 'Luna' and 'Topar' pubescent wheatgrasses were used in the Sidney and last study at Dickinson, repsectively. However, the differences in cultivars probably did not account for all differences in forage yield of IPW among studies.

High forage yields the first few years after secding are probably partially due to summer fallowing before seeding. Summer fallowing would not only increase the amount of soil water stored but also available nitrogen in the soil. Black and Wight (1979) reported that roots in a native range site adjacent to the Sidney site contained $181 \mathrm{~kg} \mathrm{~N} /$ ha before it was plowed and seeded. If we assume that it requires 3 to 4 years for roots to decay and release their $N$, then during 2 years of summer fallow plus an establishment year would mineralize about 135 to $180 \mathrm{~kg} \mathrm{~N} / \mathrm{ha}$.

The high correlations obtained by Stitt (1958) could not have been obtained if low precipitation had occurred during the first few years of the study. The effects of stand age on forage yields need to be removed as a source of variation before monthly precipitation is correlated with forage yields.

\section{Conclusions}

Data presented in this paper demonstrate that for all species studied except GN, forage production lost during seedbed preparation and deferment during the establishment year was compen- 
sated for by the high forage production during the first 3 years after establishment. The economics of seeding forages needs to be reconsidered after taking the effects of stand age on forage production into account. For example, forage production of $\mathbb{C W}$ and IPW per centimeter of April through June precipitation during the first 3 years after establishment was double that of the next 3 years. Consequently, forage production during at least the first 6 years after establishment cannot be accurately correlated with precipitation unless stand age also is considered.

\section{Literature Cited}

Arnold, C.Y. 1959. The determination and significance of the base temperature in a linear heat unit system. Proc. Amer. Soc. Hort. Sci. 74:430-445.

Black, A.L., and J.R. Wight. 1979. Range fertilization: Nitrogen and phosphorus uptake and recovery over time. J. Range Manage. 32:349-353.

Clerk, K.W., and D.H. Heinrichs. 1957. Grass-legume mixture trials. Can. Dep. Agr. Bull.

Currie, P.O., and D.R. Smith. 1970. Response of seeded ranges to different grazing intensities in the Ponderosa pine zone of Colorado. USDA Forest Service Prod. Res. Rep. 112.

Kilcher, M.R. 1980. Influence of test period and sequence of years on results with perennial forage crops in a semiarid region. Can. J. Plant Sci. 60:1191-1201.

Kilcher, M.R., and D.H. Heinrichs. 1974. Interpretive difficulties with erratic data from perennial forage crops grown in a semiarid region. Can. J. Plant Sci. 54:457-462.
Lawrence, T., and D.H. Heinrichs. 1968. Long-term effects of row spacing and fertilizer on the productivity of Russian wild ryegrass. Can. J. Plant Sci. 48:75-84.

Leyshon, A.J., M.R. Kilcher, and J.D. MeElgunn. 1981. Seeding rates and row spacings for three forage crops grown alone or in alternate grassalfalfa rows in southwestern Saskatchewan. Can. J. Plant Sci. 61:711-717.

Nyren, P.E., W.C. Whitman, and D.E. Williams. 1980. Performance of seeded native and introduced grasses in western North Dakota. North Dakota Farm Res. 37:(5)33-35.

Rogler, G.A., and H.H. Hass. 1947. Range production as related to soil moisture and precipitation on the northern Great Plains. J. Amer. Soc. Agron. 39:378-389.

Smoliak, S. 1956. Influence of climatic conditions on forage production of shortgrass rangeland. J. Range Manage. 9:89-91.

Stitt, R.E. 1958. Factors affecting yield and quality of dryland grasses. Agron. J. 50:136-138.

Thomas, J.R., and A. Osenbrug. 1959. Effect of manure, nitrogen, phosphorus, and climatic factors on the production and quality of bromegrasscrested wheatgrass hay. Agron. J. 51:63-66.

White, L.M., and J.R. Wight. 1984. Forage yield and quality of dryland grasses and legumes. J. Range Manage. 37:233-236.

Whitman, W.C., D.R. Petersen, and T.J. Conlon. 1961. Grass studies at Dickinson ... Results of clipping trials with cool season grasses. North Dakota Farm Res. 22:(2)9-14.

Whitmen, W.C., D.R. Petersen, and T.J. Conlon. 1962. Grass studies at Dickinson ... Results of clipping trials with grasses and grass-alfalfa mixtures. North Dakota Farm Res. 22:(3)4-13.

Yates, F. 1933. The analysis of replicated experiments when the field results are incomplete. Empire J. Exp. Agr. 1:129-142.

MOVING? Please try to give us

four weeks notice. Send your

present address label and this

form to Society for Range Management

2760 W. 5th Ave.

Denver, Colo. 80204

ATTACH OLD

Name ......................

HERE

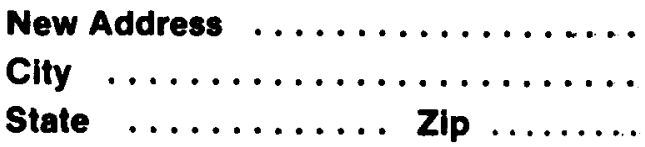

